Article

\title{
Perception of Cabin Air Quality among Drivers and Passengers
}

\author{
Doru Constantin *, Crisanta-Alina Mazilescu, Mihai Nagi, Anca Draghici \\ and Ana-Andreea Mihartescu
}

Teacher Training Department, Politehnica University Timisoara, Piata Victoriei nr 2, Timisoara 300003, Romania; alina.mazilescu@upt.ro (C.-A.M.); mihai.nagi@upt.ro (M.N.); anca.draghici@upt.ro (A.D.);

andreea.mihartescu@upt.ro (A.-A.M.)

* Correspondence: doru.d.constantin@gmail.com or doru.constantin@upt.ro; Tel.: +40-723-227-617

Academic Editors: Daniel A. Vallero and Marc Rosen

Received: 28 May 2016; Accepted: 23 August 2016; Published: 29 August 2016

\begin{abstract}
Air analysis inside vehicles is a problem that can be interpreted from several perspectives. This research is oriented towards the perception of air quality within a car, regarding a situation of cars in stationary traffic. Carbon dioxide measurements were made using a Trotec Data Logger Air Quality $\mathrm{CO}_{2}$ BZ30 machine inside different standing vehicles with up to five occupants, with and without circulating air. The perception of the air quality was measured on a Likert-type scale with seven levels on a sample group of 60 students. The results highlight, on the one hand, the conditions under which the $\mathrm{CO}_{2}$ in the cabin air can reach concentrations which are, according to new data, considered to influence the cognitive capacity of occupants in the car, and on the other hand, they present a global assessment of the air quality in the vehicle when critical values of $\mathrm{CO}_{2}$ have been reached. If the air exchange rates inside a car are low, this degrades the air quality in such a way that it affects the concentration and reactions necessary for safe driving without perceiving any discomfort that would put the drivers or the passengers on alert.
\end{abstract}

Keywords: cabin; air quality; carbon dioxide measurements; safe driving

\section{Introduction}

From the perspective of sustainable development in the automotive field, comfort is no longer solely derived from architecture, engineering, social sciences, or the humanities. Increasingly, the quality of the ambient environment is influencing the comfort of the vehicle occupants. Thus, the relationship between pollutant concentrations and comfort may also affect the safety of individuals and the public at large. Sustainable transportation policies are closely related to the potential contribution of this sector in order to decrease in $\mathrm{CO}_{2}$ emissions [1-3]. Air quality and carbon dioxide emissions, especially in urban transportation and air transportation, is one of the major points of interest of researchers [4]. The concern of car manufacturers of air quality inside and outside the vehicle should combine and satisfy both the problematic aspects related to comfort and those related to traffic safety, without neglecting any aspects of reducing energy consumption. Watertight modern passenger vehicles greatly reduce heat loss and noise from the car and from outside of it, but prevent natural air renewal inside the vehicle. Also, the very good performances of the new engines reduce the loss of energy, but this energy was usable during the winter to heat the passenger compartment.

In this context of constraints regarding comfort, risk, cost and power consumption, we intend to conduct a study on the air quality in a vehicle, and more specifically, we want to study the perception of the air quality in terms of whether the concentration of carbon dioxide can reach values that can influence the attention and decision capacity of the driver. This influence has been the subject of debate for many researchers in recent years [5-13]. To this end we will review research that highlights the 
effects of carbon dioxide on health and cognitive performance that can be identified in the case of vehicle drivers.

Carbon dioxide is a component of the air, naturally emitted by living beings through breathing. Also called carbonic gas, $\mathrm{CO}_{2}$ is one of the air pollutants. The presence of $\mathrm{CO}_{2}$ in a given air sample is commonly expressed as parts per million (ppm). Studies show that the concentration of $\mathrm{CO}_{2}$ in the air inside inhabited environments usually varies between $350 \mathrm{ppm}$ and $2500 \mathrm{ppm}$ [14-18], but can also reach values of $3000 \mathrm{ppm}$ or $4000 \mathrm{ppm}[19,20]$ depending on the number of people present and the ventilation of the air. At a global and European level there are regulations regarding the ventilation of inhabited environments without presenting scientific arguments regarding the setting of these explicit thresholds of $\mathrm{CO}_{2}$ levels for residential and non-residential buildings [21]. The French rules indicate a level of $1000 \mathrm{ppm}$ of $\mathrm{CO}_{2}$ under the normal occupancy of non-residential buildings, with a tolerance margin for places where smoking is prohibited, where values up to $1300 \mathrm{ppm}$ are allowed. In 2004 a value of $5000 \mathrm{ppm}$ was regulated for occupational exposure.

The same limit is set in 19 other European countries, also establishing short-term exposures between 10,000 and 30,000 ppm [21,22].

Table 1 lists several values regulated or recommended for the $\mathrm{CO}_{2}$ level in residences, classrooms and conference rooms.

Table 1. $\mathrm{CO}_{2}$ standards and guidelines for indoor spaces.

\begin{tabular}{ccc}
\hline & $\mathbf{C O}_{\mathbf{2}}$ Values Regulated or Recommended \\
\cline { 2 - 3 } & in Residences & in Classrooms \\
\hline Belgium [21] & $500 \mathrm{ppm}$ & $500 \mathrm{ppm}$ \\
Netherlands [21] & $1000-1500 \mathrm{ppm}$ & $1200 \mathrm{ppm}$ \\
Finland [21] & $1200 \mathrm{ppm}$ & $1200 \mathrm{ppm}$ \\
UK & - & $1500 \mathrm{ppm}$ \\
US [23] (ASHRAE) & $1000 \mathrm{ppm}$ & $1000 \mathrm{ppm}$ \\
US [24] (OSHA) & $1000 \mathrm{ppm}$ & $1000 \mathrm{ppm}$
\end{tabular}

ASHRAE-American Society of Heating, Refrigeration and Air Conditioning Engineers; OSHA-Occupational Safety and Health Administration.

In what concerns the $\mathrm{CO}_{2}$ standards for vehicles, we only found the standards of the Taiwan Environmental Protection Administration established at $1000 \mathrm{ppm}$ for $8 \mathrm{~h}-\mathrm{CO}_{2}$ for buses and the air quality guideline of the Hong Kong Environmental Protection Department ( $1 \mathrm{~h}-\mathrm{CO}_{2}: 2500 \mathrm{ppm}$ for Level 1 for buses) (see Table 2) [5].

Level 1 represents good air quality at which there is no health concern identified.

Level 2 represents the air quality at which there is no health concern identified.

Table 2. Numerical values of carbon dioxide for the two-level air quality guidelines established for ferries [25] and buses [26].

\begin{tabular}{|c|c|c|}
\hline \multirow{2}{*}{ Parameters } & \multicolumn{2}{|c|}{ Air Quality Guidelines } \\
\hline & Level 1 & Level 2 \\
\hline Carbon dioxide & $2500 \mathrm{ppm}\left(4500 \mathrm{mg} / \mathrm{m}^{3}\right)$ & $3500 \mathrm{ppm}\left(6300 \mathrm{mg} / \mathrm{m}^{3}\right)$ \\
\hline
\end{tabular}

Williams presents several clarifications from the National Institute of Occupational Safety and Health (NIOSH), indicating the potential effects, limitation and exposure limits in the case of a very high work rate and while at rest (see Table 3) [10]. 
Table 3. Potential effects, limitations and exposure limits in the case of a very high work rate and at rest [10].

\begin{tabular}{ccccc}
\hline & \multicolumn{2}{c}{ At Rest $\left(\mathbf{6 5} \mathbf{W} \cdot \mathbf{m}^{\mathbf{2}}\right)$} & \multicolumn{2}{c}{ Very, Very High Work Rate $\left(\mathbf{4 0 0} \mathbf{W} \cdot \mathbf{m}^{2}\right)$} \\
\hline $\mathbf{p p m ~ C O} \mathbf{C O}_{2}$ & Potential Effects and/or Limitations & $\begin{array}{c}\text { Exposure } \\
\text { Limit (Time) }\end{array}$ & $\begin{array}{c}\text { Potential Effects and/or } \\
\text { Limitations }\end{array}$ & $\begin{array}{c}\text { Exposure Limit } \\
\text { (Time) }\end{array}$ \\
\hline $\mathbf{2 5 , 0 0 0}$ & Increase in ventilation & unknown & Increase in ventilation & $2 \mathrm{~h}$ \\
\hline $\mathbf{3 0 , 0 0 0}$ & $\begin{array}{c}\text { Increase in ventilation } \\
\text { No restrictions within the exposure limit }\end{array}$ & $15 \mathrm{~h}$ & Increase in ventilation & $30 \mathrm{~min}$ \\
\hline $\mathbf{5 0 , 0 0 0}$ & $\begin{array}{c}\text { Increase in ventilation } \\
\text { No restrictions within the exposure limit }\end{array}$ & $8 \mathrm{~h}$ & $\begin{array}{c}\text { Increase in ventilation } \\
\text { Collapse/unconsciousness }\end{array}$ & $5 \mathrm{~min}$ \\
\hline $\mathbf{7 0 , 0 0 0}$ & $\begin{array}{c}\text { Increase in ventilation } \\
\text { Severe limitations on activity }\end{array}$ & $<30 \mathrm{~min}$ & Collapse/unconsciousness & $\mathrm{n} / \mathrm{a}$ \\
\hline $\mathbf{1 0 0 , 0 0 0}$ & $\begin{array}{c}\text { Increased heart rate } \\
\text { Collapse/unconsciousness }\end{array}$ & $<2.0 \mathrm{~min}$ & Collapse/unconsciousness & $\mathrm{n} / \mathrm{a}$ \\
\hline
\end{tabular}

Carbon dioxide $\left(\mathrm{CO}_{2}\right)$ was selected as a proxy indicator of air quality because its concentration within an indoor environment indicates the effectiveness of the ventilation system and the adequacy of the ventilation [25].

There are important physical and physiological responses to $\mathrm{CO}_{2}$ exposure throughout the body. $\mathrm{CO}_{2}$ is a potent stimulus of cerebral vasodilation and blood flow [10,27]. Early symptoms include a sense of "air hunger" or dyspnea and increased respiration and headaches. A higher $\mathrm{CO}_{2}$ concentration produces heart palpitations, confusion, severe dyspnea, vomiting, disorientation and hypertension [10,28]. $\mathrm{CO}_{2}$ is also considered a potent stimulus of pulmonary minute ventilation [27]. Due to a low $\mathrm{pH}$ in the blood (which means a high level of acid), the respiratory center in the brain stimulates the respiratory muscles that increase ventilation [8]. $\mathrm{CO}_{2}$ can also alter the intracellular $\mathrm{pH}$, thus having effects on the metabolism [10].

Existing studies have tried to establish a link between carbon dioxide concentration and its effects on both health and performances and also on the perception of the state of comfort [13].

\section{1. $\mathrm{CO}_{2}$ Effects on Health}

The studies conducted in order to identify the effects of carbon dioxide on health have revealed symptoms related to unhealthy building syndrome (sick building syndrome) [29], respiratory symptoms [16] related to asthma [19] and other effects such as respiratory and otorhinolaryngology infections, rash [30] or general symptoms such as fatigue and headache [17].

Cardiovascular effects have also been highlighted. For example, at a concentration higher than $5 \%(50,000 \mathrm{ppm})$, effects such as the increase of blood pressure and heart rate [31], the occurrence of extra systoles during effort [32] or the increase of blood supply to the kidneys and brain have been identified [33]. Also, at levels higher than 50,000 ppm, the effects on the central nervous system were highlighted, such as headache symptoms, dizziness and physical arousal [34], and even visual disturbances [32] at concentrations above 100,000 ppm. Starting from 1\% (or 10,000 ppm), an exposure of 30 min may lead to early respiratory acidosis effects [33]; inhalation of air with concentrations higher than 50,000 ppm for one hour leads to lung inflammation [19,35], and exposure to levels above 200,000 ppm can cause coma and/or death [32].

\section{2. $\mathrm{CO}_{2}$ Effects on Cognitive Performances and Productivity}

Regarding the effects of carbon dioxide on cognitive performances and productivity, recent studies conducted in offices and schools show that increased ventilation above the normal recommendations indicates an increase of productivity by $5 \%-10 \%$ [36]. The recommended fresh air supply rate for school classrooms in the UK is $3 \mathrm{~L}$ per second per pupil (L/s.p) with the capacity to supply $8 \mathrm{~L} / \mathrm{s.p}$. [37]. 
Although there are few studies conducted on vehicles regarding carbon dioxide [5-7], the laboratory studies and those conducted in schools or in spacecrafts highlight alterations of the attention capacities and decision-making and academic performances [8,9,11-13,27].

Chiu, Chen and Chang showed in a recent study (2015) that high-capacity tour bus cabins with the air conditioning system operating in the recirculation mode severely lack in air exchange rate, which may negatively impact transportation safety. They found that both the driver zones and the passenger zones of the tour buses reached more than $3000 \mathrm{ppm}$ of carbon dioxide concentration, and maximum daily average concentrations of 2510.6 and $2646.9 \mathrm{ppm}$ [5].

The study led by Allen and Spengler confirms the findings of Satish, who found the statistical influence of $\mathrm{CO}_{2}$ on decision-making performance when the carbon dioxide level increases from 600 to 1000 and 2500 ppm, respectively $[9,38]$.

At $2500 \mathrm{ppm}$, large and statistically significant reductions occurred across seven scales of decision-making performance [38]. The Allen and Spengler study also shows that cognitive scores were $61 \%$ higher on the Green building day and $101 \%$ higher on the two Green+ building days than on the Conventional building day $(p<0.0001)[9,38]$.

Kajtár, Herczeg and Láng conducted four experimental studies with the following $\mathrm{CO}_{2}$ concentrations: $600,1500,3000,4000 \mathrm{ppm}$. Their results revealed that the capacity to focus declines when the $\mathrm{CO}_{2}$ concentration in the air increases up to $3000 \mathrm{ppm}$ [12]. Two other experimental studies carried out by Kajtar, Herczeg, Lang, Hrustinszky and Banhidi showed that a $\mathrm{CO}_{2}$ concentration over 3000 ppm makes the well-being and the focus of the subjects' decline [11].

Wargocki shows that performance (in addition and correction tests) significantly increases when carbon dioxide levels decrease [14]. The same author highlighted in 2007 the link between the speed of students solving tests and the increased ventilation of classrooms.

Twardella highlights both the significant correlations between the increase in ventilation and the decrease in the number of recorded errors, as well as non-significant correlations between the speed of executing tasks and focusing [39]. Two other experimental studies highlight the significant correlations between the increase in carbon dioxide levels and the decrease in performance (percent of identified errors) in a reading test [12] and a computer test [38].

There are also a few studies which do not always highlight the significant effects of $\mathrm{CO}_{2}$ 's influence on cognitive skills [31].

A recent review by National Aeronautics and Space Administration NASA examined 76 studies and reported that it is difficult to draw firm conclusions about the impact of carbon dioxide on sleep, cognition and psychomotor performance, but it is necessary to understand and clarify the risk of adverse cognition and performance effects of carbon dioxide, especially in human spaceflights [13].

\section{3. $\mathrm{CO}_{2}$ Effects on the Perception of Comfort}

The third aspect regarding the effects of carbon dioxide studied is its relationship with the perception of the state of comfort, especially with the perception of air quality. Wargocki finds that acceptability of air quality, its freshness and reduced odor perception increase significantly with the level of ventilation (and therefore with lower $\mathrm{CO}_{2}$ levels), but these differences are perceived only when entering the room [14]. In the 2004 study, none of these variables is reported as significant. Other researchers obtained significant results between $\mathrm{CO}_{2}$ reduction and the perception of air quality, specifically in connection with the freshness of the air, the perception of lower temperatures, increased perception of air movement and decreased perception of odors [14,40-43].

Recirculated air in the cabin can have benefits for the drivers who opt to put it into operation: it is considered the most effective option in terms of thermal management of the car and help to reduce fuel consumption [44]. The use of the air recirculation position leads to protection from different pollutants existing in the environment or helps reduce particles in the car [44]. The argument of effective thermal management is taken into account in the case of electric cars in order to increase the vehicle's autonomy movement. 
The buses with air conditioning operating in the recirculation mode are severely lacking in terms of the air exchange rate and consequently elevate the risk of traffic accidents because bus drivers use the air conditioning system in the recirculation mode most of the time [5].

We chose to study the air quality in cars with and without using the air recirculation setting, because we supposed that the air recirculation setting can rapidly lead to significant increases in $\mathrm{CO}_{2}$.

The hypothesis considered for the study, in a stationary car, is an atypical situation, but is frequently encountered in the following circumstances:

- when using the "drive-in" service where customers park their vehicles to enjoy an on-board service. As an example we can list drive-in restaurants, but also drive-in cinemas where people spend several hours in the car;

- in the daily traffic jams but also in occasional traffic jams, for example in cases of traffic accidents during blockages encountered when leaving or returning from vacations or when waiting at border crossing points, etc., when we are obliged to spend several hours in a stationary car.

The present research aims to study the air in vehicles from the perspective of carbon dioxide levels and the perception of air quality in cars in terms of the presence of different amounts of $\mathrm{CO}_{2}$ in the breathing air.

\section{Materials and Methods}

\subsection{Participants}

All the participants in our study were students of a technical college, 19 students from the third year and 41 students from the fourth year. A total of 60 students, young drivers and passengers (34 men, 26 women; $M=22.9$ years) participated in the assessment of the air quality during the measurement of $\mathrm{CO}_{2}$ (first evaluation). Twenty out of the 60 subjects participated in another evaluation of the air before and after the measurement of $\mathrm{CO}_{2}$. The perception of the air quality was measured on a Likert-type scale with seven levels (1-very poor; 7-very good quality of the air).

All participants signed an Informed Consent before participating in the research where they were informed about the purpose of the study, the procedure to be undergone, and the potential risks and benefits of their participation. Their participation was voluntary and they agreed to participate without remuneration.

\subsection{Vehicle Instrumentation}

Carbon dioxide measurements were made using a Trotec Data logger Air Quality $\mathrm{CO}_{2} \mathrm{BZ30}$ machine with the following technical data: $\mathrm{CO}_{2}$ sensor-NDIR (non-dispersive infrared); carbon dioxide measuring range: 0 to 9999 ppm $\mathrm{CO}_{2}$; resolution (precision) $\mathrm{CO}_{2}: 1 \mathrm{ppm}$ ( $\pm 75 \mathrm{ppm}$ or $\pm 5 \%$ of measured value); measuring range: $2 \mathrm{~s}$; readings memory: 50,000 measured values. A zero calibration was applied prior to every use.

\subsection{Design and Conduct of the Study}

The air quality assessment was carried out under the following conditions:

- one, two, three and four people in the car;

- In three vehicles: Dacia Logan, Hyundai and Renault ZE;

- In two situations: with recirculation and without recirculation of the air.

A different measurement of carbon dioxide at 10,000 ppm was reached with five people in a Dacia Logan cabin.

Our study is based on an experimental design with two groups and repeated measurements, a pre-test $T_{i}$ and a post-test $T_{f}$. 
Participants in these measurements and evaluations received an evaluation form and were given the task to evaluate the air quality on a scale from 1 to 7 (1-very poor; 7-very good quality of the air). The air quality was assessed when entering the vehicle (initial $T_{i}$ pre-test phase) and the participants remained in the vehicle until the air reached $5000 \mathrm{ppm} \mathrm{CO}_{2}$. A final $\mathrm{T}_{\mathrm{f}}$ post-test evaluation phase was conducted at $5000 \mathrm{ppm}$.

Half of the $\mathrm{CO}_{2}$ measurements and of the air quality evaluations have been performed with the recirculation mode on and half with the recirculation mode off. The cars were stationary in all cases.

We continued the experiment with another level of the variable, in which 20 out of the 60 participants assessed the air quality two more times. The first evaluation was made when entering the vehicle (initial phase). After this initial evaluation, they left the vehicle and then re-entered it after the amount of carbon dioxide reached $5000 \mathrm{ppm}$. At this time they assessed the air quality a second time $T_{f}$ (final phase). Ten out of these 20 participants assessed the air quality in cars with the recirculation mode activated and 10 in cars without recirculation.

All the cars were stationary and the results should only be interpreted under these conditions. We opted for a stationary machine in order to eliminate the influence of vehicle speed on the $\mathrm{CO}_{2}$ concentration within the cabin.

\section{Results}

\subsection{Measuring and Analyzing Carbon Dioxide in the Cockpit}

Analyzing the air quality within the cockpit is one of the aims of this article. To this end we measured how long it took the air inside the passenger compartment to reach a level of carbon dioxide concentration characterized as the $\mathrm{CO}_{2}$ limit in occupational exposure within a maximum of $8 \mathrm{~h}$ (5000-5000 parts per million).

Due to the health risks associated with carbon dioxide, the average exposure of a healthy employee during an eight-hour working shift should not exceed 5000 ppm [45].

We chose to study two relevant situations in which carbon dioxide levels easily reach values that can influence the cognitive capacity of the driver and, in extreme circumstances, can endanger the health of the passengers. We refer to the situation in which the vehicle is stationary without the air being recirculated and to a second situation in which the vehicle has the air recirculation option activated (the scenario of a car blocked in a tunnel or stuck in traffic).

Table 4 lists the average (M) and standard deviation (SD) for the measurements conducted for all three types of vehicles, with one, two, three and four persons in the cockpit. It was observed that for a single person it takes $24 \mathrm{~min}$, whereas for four persons it takes $7 \mathrm{~min}$, to reach a level of $3000 \mathrm{ppm}$ $\mathrm{CO}_{2}$, i.e., the concentration at which substantial adverse effects on cognitive performance can lead to transportation risk [38].

Table 4. The averages and standard deviations for the time span necessary for the air within the cockpit to reach certain values of $\mathrm{CO}_{2}$ (stationary vehicle without the recirculation of air).

\begin{tabular}{|c|c|c|c|c|c|c|c|c|}
\hline \multicolumn{9}{|c|}{ Stationary Vehicle without Recirculation the Air } \\
\hline \multirow[t]{2}{*}{ Level of $\mathrm{CO}_{2}(\mathrm{ppm})$} & \multicolumn{2}{|c|}{ Time in min/1 Person } & \multicolumn{2}{|c|}{ Time in $\mathrm{min} / 2$ Persons } & \multicolumn{2}{|c|}{ Time in $\mathrm{min} / 3$ Persons } & \multicolumn{2}{|c|}{ Time in $\mathrm{min} / 4$ Persons } \\
\hline & $\mathbf{M}_{1 \text { pers }}$ & $\mathrm{SD}_{1 \text { pers }}$ & $\mathbf{M}_{2 \text { pers }}$ & $\mathrm{SD}_{2 \text { pers }}$ & $\mathbf{M}_{3 \text { pers }}$ & $\mathrm{SD}_{3 \text { pers }}$ & $\mathbf{M}_{4 \text { pers }}$ & $\mathrm{SD}_{4 \text { pers }}$ \\
\hline 1.000 & $\mathrm{~T} 1=4.17$ & 0.44 & $\mathrm{~T} 1=3.22$ & 0.58 & $\mathrm{~T} 1=2.44$ & 0.58 & $\mathrm{~T} 1=1.5$ & 0.17 \\
\hline 2.000 & $\mathrm{~T} 2=12.64$ & 2.44 & $\mathrm{~T} 2=8.92$ & 0.5 & $\mathrm{~T} 2=5.67$ & 0.5 & $\mathrm{~T} 2=4.05$ & 0.35 \\
\hline 3.000 & $\mathrm{~T} 3=24.41$ & 3.50 & $\mathrm{~T} 3=17.08$ & 0.76 & $\mathrm{~T} 3=10.33$ & 0.76 & $\mathrm{~T} 3=7.5$ & 0.73 \\
\hline 4.000 & $\mathrm{~T} 4=38.78$ & 3.91 & $\mathrm{~T} 4=26.72$ & 1.29 & $\mathrm{~T} 4=15.11$ & 1.29 & $\mathrm{~T} 4=9.89$ & 0.19 \\
\hline 5.000 & $\mathrm{~T} 5=56$ & 5.29 & $\mathrm{~T} 5=38.19$ & 1.23 & $\mathrm{~T} 5=20.89$ & 1.23 & $\mathrm{~T} 5=13.05$ & 1.29 \\
\hline
\end{tabular}

Table 5 lists the time necessary for the cockpit air with five people inside to increase from a level of $350 \mathrm{ppm}$ to $10,000 \mathrm{ppm}$, the limit at which the first signs of respiratory acidosis can occur. The measurement was made in a stationary Dacia Logan. The time needed to reach 10,000 ppm was $28 \mathrm{~min}$. 
Table 5. Time (in seconds or minutes) needed for the air breathed by five persons to reach 10,000 ppm.

\begin{tabular}{cccccc}
\hline Level of $\mathbf{C O}_{\mathbf{2}}$ & $\begin{array}{c}\text { Time of } \\
\text { Measurement }\end{array}$ & $\begin{array}{c}\boldsymbol{\Delta} \mathbf{t}(\mathbf{m i n}) \text { between } \\
\text { 2 Levels of } \mathbf{C O}_{\mathbf{2}}\end{array}$ & $\begin{array}{c}\boldsymbol{\Delta} \mathbf{t}(\mathbf{s}) \\
\text { 2 Levels of } \mathbf{C O}_{\mathbf{2}}\end{array}$ & $\begin{array}{c}\mathbf{T}(\mathbf{s}) \\
\text { Cumulative }\end{array}$ & $\begin{array}{c}\mathbf{T}(\mathbf{m i n}+\mathbf{s}) \\
\text { Cumulative }\end{array}$ \\
\hline $350 \mathrm{ppm}$ & $09: 46: 49$ & 00.00 & 00 & 00 & $0 \mathrm{~min}$ \\
$1000 \mathrm{ppm}$ & $09: 49: 23$ & $2 \min 34 \mathrm{~s}$ & 154 & 154 & $2 \mathrm{~min} 34 \mathrm{~s}$ \\
$2000 \mathrm{ppm}$ & $09: 51: 29$ & $2 \min 06 \mathrm{~s}$ & 126 & 280 & $4 \mathrm{~min} 40 \mathrm{~s}$ \\
$3000 \mathrm{ppm}$ & $09: 53: 55$ & $2 \min 26 \mathrm{~s}$ & 146 & 426 & $7 \mathrm{~min} 06 \mathrm{~s}$ \\
$4000 \mathrm{ppm}$ & $09: 56: 21$ & $2 \min 26 \mathrm{~s}$ & 146 & 572 & 9 min $32 \mathrm{~s}$ \\
$5000 \mathrm{ppm}$ & $09: 58: 41$ & $2 \min 20 \mathrm{~s}$ & 140 & 712 & $11 \mathrm{~min} 52 \mathrm{~s}$ \\
$6000 \mathrm{ppm}$ & $10: 01: 37$ & $2 \min 58 \mathrm{~s}$ & 178 & 890 & $14 \mathrm{~min} 50 \mathrm{~s}$ \\
$7000 \mathrm{ppm}$ & $10: 04: 17$ & $2 \min 40 \mathrm{~s}$ & 160 & 1050 & $17 \mathrm{~min} 30 \mathrm{~s}$ \\
$8000 \mathrm{ppm}$ & $10: 07: 25$ & $3 \min 08 \mathrm{~s}$ & 188 & 1238 & $20 \mathrm{~min} 38 \mathrm{~s}$ \\
$9000 \mathrm{ppm}$ & $10: 11: 02$ & $3 \min 37 \mathrm{~s}$ & 217 & 1455 & $24 \mathrm{~min} 15 \mathrm{~s}$ \\
$10,000 \mathrm{ppm}$ & $10: 14: 52$ & $3 \min 50 \mathrm{~s}$ & 230 & 1685 & $28 \mathrm{~min} 05 \mathrm{~s}$ \\
\hline
\end{tabular}

$\min =$ minute; $\mathrm{s}=$ seconds.

We include Figure 1 to show the time during which the carbon dioxide increased from 350 to 10,000 ppm (for five persons in a Dacia Logan).

Evolution of $\mathrm{CO}_{2}$ concentration inside the car as a function of time

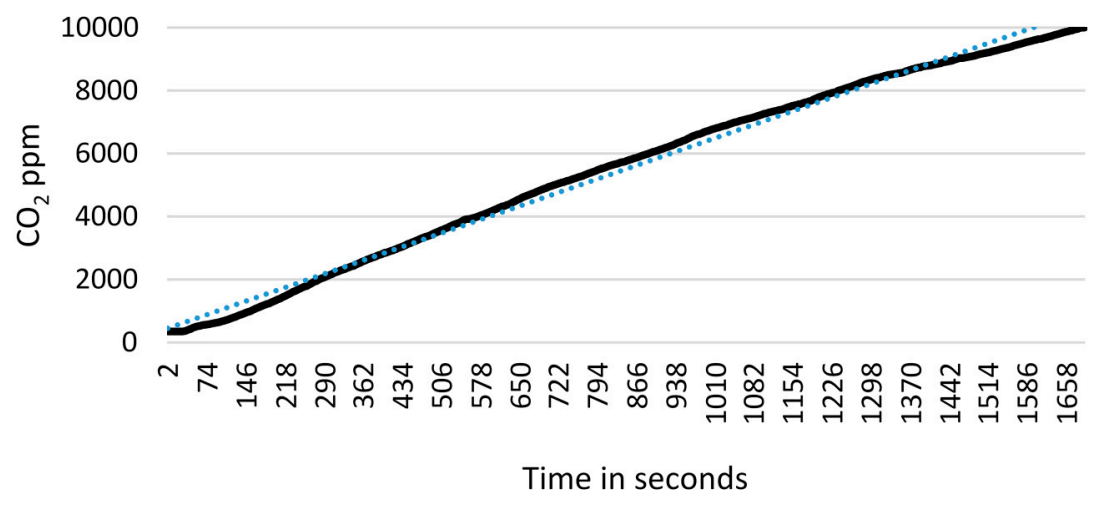

Figure 1. The graph curve of carbon dioxide in time.

The $\mathrm{CO}_{2}$ curve indicates the amount of carbon dioxide and its evolution over time in a stationary vehicle with the recirculated air mode on, with five passengers. The measurements show that in about $12 \mathrm{~min}$, the carbon dioxide level reached the limit for occupational exposure (5000 ppm). In about $28 \mathrm{~min}$, the amount of carbon dioxide reached the level at which the first signs of respiratory acidosis appear (10,000 ppm). This plot suggests that $\mathrm{CO}_{2}$ does not approach a steady-state concentration, not even at 10,000 ppm. This could be dangerous, calling for an alert, e.g., an alarm system triggered at this concentration.

Table 6 indicates the maximum, minimum and average scores for the three characteristics measured in a stationary Dacia Logan with five people in the cockpit. The sampling frequency was of $2 \mathrm{~s}$, yielding 1581 measurements.

Another situation was the study of the air quality in the cockpit with the air being recirculated. There are usually economic reasons for which some people wish to recycle the air inside the cockpit.

However, increasing carbon dioxide levels can endanger the attention of the driver and even the lives of the passengers. 
Table 6. Minimum, maximum and average $\mathrm{CO}_{2}$, temperature and air humidity during the time in which the carbon dioxide level has risen from 350 to $10,000 \mathrm{ppm}$.

\begin{tabular}{cccc}
\hline & Maximum & Minimum & Average \\
\hline Carbon dioxide & $10,000 \mathrm{ppm}$ & $350 \mathrm{ppm}$ & $5174.5 \mathrm{ppm}$ \\
Temperature & $29.20^{\circ} \mathrm{C}$ & $24.20^{\circ} \mathrm{C}$ & $26.8^{\circ} \mathrm{C}$ \\
Humidity & 45.50 & 30.30 & 37.9 \\
\hline
\end{tabular}

Table 7 lists the time during which the air breathed by the occupants of the vehicles reached certain values of carbon dioxide, in the case of a stationary vehicle with recycled air. Recirculation was carried out at a flow rate of $105.64 \mathrm{~m}^{3} / \mathrm{h}$ with ventilation activated at level 2 out of 4 .

Table 7. The time during which the air breathed by the occupants of the vehicles reached certain values of carbon dioxide in the case of a stationary vehicle with recycled air.

\begin{tabular}{|c|c|c|c|c|c|c|c|c|}
\hline \multicolumn{9}{|c|}{ Stationary Vehicle with Recycled Air } \\
\hline \multirow{2}{*}{$\frac{\text { Level of } \mathrm{CO}_{2}}{(\mathrm{ppm})}$} & \multicolumn{2}{|c|}{ Time in min/1 Person } & \multicolumn{2}{|c|}{ Time in $\mathrm{min} / 2$ Persons } & \multicolumn{2}{|c|}{ Time in $\mathrm{min} / 3$ Persons } & \multicolumn{2}{|c|}{ Time in min/4 Persons } \\
\hline & $\mathrm{M}_{1 \text { pers }}$ & $\mathrm{As}_{1 \text { pers }}$ & $\mathrm{M}_{2 \text { pers }}$ & $\mathrm{As}_{2 \text { pers }}$ & $M_{3 \text { pers }}$ & $\mathrm{As}_{3 \text { pers }}$ & $\mathrm{M}_{4 \text { pers }}$ & $\mathrm{As}_{4 \text { pers }}$ \\
\hline 1.000 & $\mathrm{~T} 1=4.58$ & 0.38 & $\mathrm{~T} 1=2.75$ & 0.50 & $\mathrm{~T} 1=2.81$ & 0.50 & $\mathrm{~T} 1=1.83$ & 0.17 \\
\hline 2.000 & $\mathrm{~T} 2=13.59$ & 2.15 & $\mathrm{~T} 2=8.86$ & 0.33 & $\mathrm{~T} 2=6.67$ & 0.33 & $\mathrm{~T} 2=4.39$ & 0.54 \\
\hline 3.000 & $\mathrm{~T} 3=25.67$ & 3.34 & $\mathrm{~T} 3=17.53$ & 1.25 & $\mathrm{~T} 3=11.97$ & 1.25 & $\mathrm{~T} 3=7.83$ & 1.04 \\
\hline 4.000 & $\mathrm{~T} 4=40.44$ & 3.81 & $\mathrm{~T} 4=27.69$ & 2.96 & $\mathrm{~T} 4=18.06$ & 2.96 & $\mathrm{~T} 4=12.19$ & 3.81 \\
\hline 5.000 & $\mathrm{~T} 5=58.58$ & 6.14 & $\mathrm{~T} 5=40.53$ & 4.73 & $\mathrm{~T} 5=25.92$ & 4.73 & $\mathrm{~T} 5=15.53$ & 2.61 \\
\hline
\end{tabular}

The flow rate was measured using a TA 300 wire anemometer. The TA 300 Trotec had an accuracy of $\pm 5 \%$ of +1 measurement unit and a 0.01 resolution. The values measured in the circulation mode are compatible and fit into the instrument's accuracy class.

Table 7 and Figure 2 show that the $\mathrm{CO}_{2}$ concentration in the cabin increased from 1000 to $5000 \mathrm{ppm}$ according to the time span and the number of persons in the car, with the air being recirculated. In the case of a single person, $58 \mathrm{~min}$ are needed for the air to reach $5000 \mathrm{ppm}$, while for four people, $15 \mathrm{~min}$ are needed to reach the same concentration of carbon dioxide.

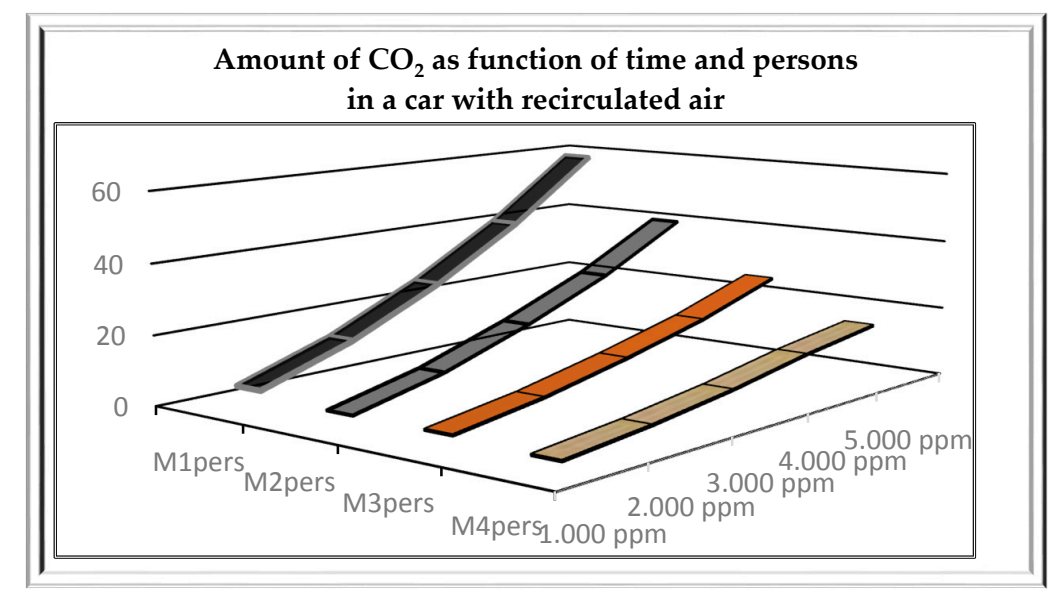

Figure 2. Amount of $\mathrm{CO}_{2}$ according to time span and number of people in a car with recirculated air.

\subsection{Analysis of the Air Quality Perception}

The air quality analysis was based on the perception of the participants toward the study and consisted of a global assessment of the air quality at two different times: at the beginning of the carbon dioxide measurements $\left(\mathrm{T}_{\mathrm{i}}\right)$, and at the end of the measurements $\left(\mathrm{T}_{\mathrm{f}}\right)$ at $5000 \mathrm{ppm}$. The perception of the air quality was measured on a Likert-type scale with seven levels: 1 , very poor; 7 , very good quality of the air. 
Our air quality study is based on an experimental design with two groups and repeated measurements, a $T_{i}$ pre-test and a $T_{f}$ post-test. The independent variable has two levels of variation (with recirculation and without recirculation) measured in the initial $T_{i}$ pre-test phase and in the final $\mathrm{T}_{\mathrm{f}}$ post-test phase. Since the data obtained on a Likert scale is ordinal data, we used nonparametric analysis tests.

\subsubsection{Comparisons between the Two Groups of Participants (with and without Recirculated Air)}

The comparative analysis conducted using the Mann-Whitney test shows that the scores obtained in the Ti pre-test phase with the group of participants who stayed in the car with the air being recirculated do not differ significantly from the scores obtained in the Ti pre-test phase of the evaluation conducted with the group of participants who stayed in the car without the air being recirculated $(\mathrm{U}=450 ; \mathrm{N} 1=30 ; \mathrm{N} 2=30 ; p=1)$. This result is obvious because both groups had the same relatively low $(350 \mathrm{ppm}) \mathrm{CO}_{2}$ concentrations, so they would be expected to have similar scores.

Participant post-test scores showed a divergence between the participants in vehicles with recirculated air versus those in vehicles without air recirculation, as indicated by the statistically significant difference in the Mann-Whitney test results $(\mathrm{U}=194, \mathrm{~N} 1=30 ; \mathrm{N} 2=30 ; p=0.001)$.

The results of both comparisons are shown in Table 8.

Table 8. Results of the Mann-Whitney test.

\begin{tabular}{|c|c|c|c|c|c|c|c|c|}
\hline \multirow{2}{*}{\multicolumn{2}{|c|}{ Criterion }} & \multirow{2}{*}{$\mathbf{N}$} & \multirow{2}{*}{$\begin{array}{l}\text { Mean } \\
\text { Rank }\end{array}$} & \multirow{2}{*}{$\begin{array}{l}\text { Sum of } \\
\text { Ranks }\end{array}$} & \multicolumn{4}{|c|}{ Test Statistics } \\
\hline & & & & & Mann-Whitney U & Wilcoxon W & $\mathbf{Z}$ & Asymp. Sig. (2-Tailed) \\
\hline \multirow{2}{*}{$\begin{array}{l}\text { Ti initial } \\
\text { (pre-test) }\end{array}$} & $\mathrm{R}(-)$ & 30 & 30.50 & 915.00 & \multirow{2}{*}{450.000} & \multirow{2}{*}{915.000} & \multirow{2}{*}{0.000} & \multirow{2}{*}{1.000} \\
\hline & $\mathrm{R}(+)$ & 30 & 30.50 & 915.00 & & & & \\
\hline \multirow{2}{*}{$\begin{array}{c}\text { Tf final } \\
\text { (post-test) }\end{array}$} & $\mathrm{R}(-)$ & 30 & 21.98 & 659.50 & \multirow{2}{*}{194.500} & \multirow{2}{*}{659.500} & \multirow{2}{*}{-4.070} & \multirow{2}{*}{0.000} \\
\hline & $\mathrm{R}(+)$ & 30 & 39.02 & 1170.5 & & & & \\
\hline
\end{tabular}

\subsubsection{Comparisons of the Two Groups between the $T_{i}$ Pre-Test and $T_{f}$ Post-Test}

The comparisons between the $T_{i}$ pre-test and the $T_{f}$ post-test phases have been made separately for each group, but also for both groups.

The comparative analysis, performed using the Wilcoxon Test $(\mathrm{N}=60, \mathrm{z}=6.73, p=0.000)$, shows that there is a significant difference in the air quality assessment between the $T_{i}$ pre-test and the $T_{f}$ post-test phases, for all participants.

In the case of the group with the recirculated air, the results of the Wilcoxon Test show that in the $\mathrm{T}_{\mathrm{f}}$ post-test phase, the air with a concentration of $5000 \mathrm{ppm}$ was considered to have a poorer quality than the air in the $\mathrm{T}_{\mathrm{i}}$ pre-test phase, with $350 \mathrm{ppm} \mathrm{CO}_{2}(\mathrm{~N}=30, \mathrm{z}=4.84, p=0.000)$.

A significant difference was also found in the case of the group without air recirculation, between perceptions of the air with $350 \mathrm{ppm}$ and perceptions of the air with $5000 \mathrm{ppm}(\mathrm{N}=30, \mathrm{z}=4.76$, $p=0.000$ ), in this latter situation the air being considered of a lower quality as compared to the initial evaluation.

\subsubsection{Comparisons of Three Groups in the $T_{f}$ Post-Test Phase}

We wanted to know whether there are differences between the two groups who participated in measuring the $\mathrm{CO}_{2}$ level and the third group that only participated in the evaluation of the air re-entering in the passenger compartment after the air had reached $5000 \mathrm{ppm}$.

We have applied the Kruskal-Wallis test in order to identify the difference between the perceptions of the air quality in the $T_{\mathrm{f}}$ post-test phase between all three groups mentioned. The results (chi-square $=29.16 ; p=0.001$ ) indicate that there are significant differences between the participants' assessments of the air quality in the cabin. 
The results obtained (average rank for the three groups) show that the best air quality was perceived by those who stayed in the cars with recirculated air $(\mathrm{M} 1=56.73)$ and the poorest air quality was evaluated by those who stayed outside the cockpit during the increase in the amount of $\mathrm{CO}_{2}(\mathrm{M} 3=23.83)$.

\subsubsection{General Assessments of the Air Quality}

Although there are significant differences regarding the perception of air quality at $350 \mathrm{ppm}$ and at $5000 \mathrm{ppm}$, the overall air quality assessment is positive both for the group of 60 participants (G60) who stayed in the car until the $\mathrm{CO}_{2}$ level increased to $5000 \mathrm{ppm}$, and for the 20 participants (G20) who left the car after the initial evaluation and then re-entered the car for the final evaluation at $5000 \mathrm{ppm}$.

As seen in Figure 3, a percentage of $81.67 \%$ of the G60 participants assessed the air at $5000 \mathrm{ppm}$ as being of a good or quite good quality and $13.33 \%$ considered the air to be neither good nor bad.

Although the differences in the perception of air quality differ significantly between the two groups mentioned, G20 does not consider the air quality to be poor. Specifically, $30 \%$ of them believed that the air quality is poor or quite poor, while 35\% considered that the air is neither good nor bad, and $35 \%$ believed the air quality to be good or quite good.

The ranking of the quality of the indoor air, according to the European norm EN 13779, shows that a difference between the indoor and the outdoor air greater than $1000 \mathrm{ppm} \mathrm{CO}_{2}$ is considered a low air quality [21]. In regards to this ranking, our results show that the majority of the study participants assessed the air, which in reality was of a low quality, as being good quality air.

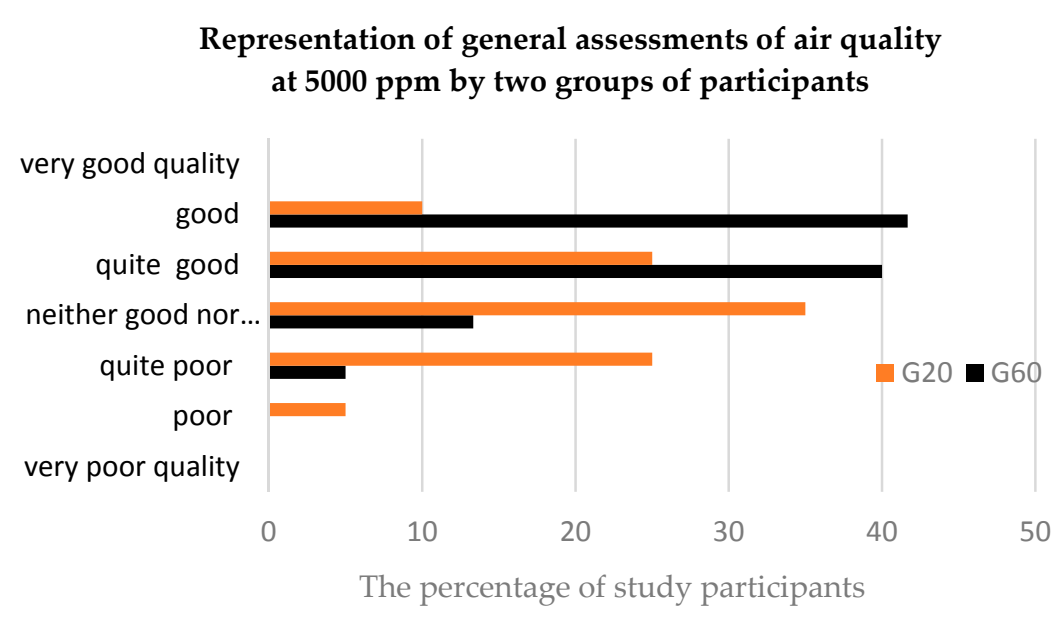

Figure 3. Representation of general assessments of air quality at $5000 \mathrm{ppm}\left(\mathrm{T}_{\mathrm{f}}\right)$.

This situation in which stale air is perceived as good air must attract the attention of those responsible for traffic safety. They might require air quality regulation and control devices, because air whose characteristics as what regards the level of $\mathrm{CO}_{2}$ is considered by many researchers to be air that can affect the cognitive abilities and the psychomotor reactions of the drivers.

\section{Discussion}

From the perspective of sustainable development, the energy efficiency of a vehicle is paramount for the preoccupations regarding comfort within the vehicles, but a concerted dialogue of specialists is required to study air, ambience and car interiors.

The aims of this article are to identify and highlight the conditions under which the air quality in vehicles can reach $\mathrm{CO}_{2}$ concentrations which might influence the attention span and the cognitive abilities of drivers. The study also investigated how the perception of air quality changes with the $\mathrm{CO}_{2}$ concentration.

The participants' perception of air quality varied considerably. Between the initial Ti and the final Tf phases of the evaluation, the carbon dioxide level in the air inside the vehicle increased from about 
$350 \mathrm{ppm}$ to $5000 \mathrm{ppm}$. This difference in air quality was emphasized in the evaluations given by the participants. All of them ascertain that the quality of the air decreased after the $\mathrm{CO}_{2}$ increased.

The participants who stayed in cars with the recirculation mode on perceived, at $5000 \mathrm{ppm}$, the quality of the air as being better compared to those who stayed in cars without the air being recirculated. This result can be explained by the fact that the existing ventilation, when the air recirculation is started, leads to an increase in the perception of the air quality.

The participants who stayed outside the cockpit perceived the quality of the air (at $5000 \mathrm{ppm}$ ) as being lower compared to those who stayed in the cabin while the level of $\mathrm{CO}_{2}$ increased. This result suggests that there is an accommodation with polluted air and it is perceived as being of a higher quality than it actually is.

Although differences were identified, the global assessment of the air quality is not negative, but rather the air quality evaluations conducted by the three groups of participants indicate that at $5000 \mathrm{ppm}$ the air is not perceived as being of a low quality. The respondent underestimated the measured concentration.

Carbon dioxide measurements performed in a stationary vehicle show that reaching the limit of $5000 \mathrm{ppm}$ ranges from $13 \mathrm{~min}$ (for four people) to $56 \mathrm{~min}$ (for one person). When this limit is exceeded, carbon dioxide can have negative effects on both the driver and the passengers because the research of Fisk and Satish highlights the deterioration of focus and of the decision-making abilities starting at values of $1000 \mathrm{ppm}$ [46].

The cabin of a car is a relatively tightly closed space [44] in which the occupants can spend more or less time. If the inside air is recirculated, the air quality in the cockpit can drop rapidly and the air inside the passenger compartment becomes unhealthy [5].

Air recirculation is recommended in situations such as when one wishes to isolate the driver and the passenger compartment from the outside air which can sometimes be polluted by different air pollutants, such as the air inside tunnels or on dusty roads.

In real life, the recirculation button is used when people want to heat or cool the air from the passenger compartment faster, which due to the air passing through the air conditioning system is increasingly warmer/colder, instead of letting the warm (cool) air in from the outside. There are also environmental and economic reasons why some people wish to recirculate the inside air. In order to reduce fuel consumption used for cooling (during summer), people opt for recirculating the air, thus assuming certain inconveniences such as misting, without being aware of the possible effects of the increase in carbon dioxide. In an electric car in which the energy consumed in order to heat the air is more appreciated than in other cars because it depends on the travel distance, the temptation to save energy and keep the air warm (or cold) is quite big and may underlie some decisions (such as recirculating the air), and this sometimes entails effects on the driving of the car as well as on the health of its occupants.

The results of this study may be useful to any driver who has assumed an ecological conduct and aimed to reduce fuel consumption and $\mathrm{CO}_{2}$ emissions by limiting the use of air conditioning. More recirculation means less energy, but it is important for drivers to be aware of the risks linked to an increased concentration of carbon dioxide. The fractional air recirculation method could be a simple innovative way of improving air quality, in order to maintain a level of $\mathrm{CO}_{2}$ that does not affect the cognitive capacity of the driver and of the passengers, and of contributing to gaining energy.

In conclusion, the increase in the carbon dioxide level above certain limits can be achieved in the everyday traffic conditions and while parking over a short period of time (from $15 \mathrm{~min}$ to $1 \mathrm{~h}$ ). If the air inside a car is not sufficiently ventilated with fresh air, it degrades the air quality in such a way that it affects the focus and reactions necessary for safe driving.

This situation may generate some risks for the occupants without them perceiving any discomfort that would put the drivers or the passengers on alert.

Driving is a very common, highly complex task that requires cognition during every routine task, but also when it comes to higher-level decision tasks [47]. Driving typically involves three classes of 
task processes: operational processes for stable driving, tactical processes that govern safe interactions with the environment and other vehicles, and strategic processes for higher-level reasoning and planning [48].

Even if, for the moment, $\mathrm{CO}_{2}$ alone is not considered an indicator of the chemical pollution of indoor air, from the point of view of road safety, $\mathrm{CO}_{2}$ measurement is very important for drivers, for whom psychological evaluation targets the cognitive capacities (attention, decision, etc.) which ensure safe driving. Consequently, we consider it useful to have a monitoring system for the $\mathrm{CO}_{2}$ level in the public transportation system, as well as in personal cars, especially because the air with a high content of $\mathrm{CO}_{2}$ is not perceived as stale air.

The $\mathrm{CO}_{2}$ levels in our atmosphere are rapidly increasing. Climatologists and other scientists have warned for more than half a century that the accumulation of $\mathrm{CO}_{2}$ and other greenhouse gases in the atmosphere is leading to global warming and other significant climatic, ecological, and societal changes. In 1900 the ambient atmosphere was below 300 ppm; now the average ambient concentration of $\mathrm{CO}_{2}$ is about $350-400$ ppm and the level predicted by the end of the 21st century is around 800-1000 ppm. This increase may have implications on all of society, especially in jobs with critical responsibilities such as surgeons, air traffic controllers or drivers [8]. Lowering $\mathrm{CO}_{2}$ is important from a transportation safety standpoint. A global awareness of this issue may enable a change in practice on $\mathrm{CO}_{2}$ emission activities.

Acknowledgments: The related findings were gained through our work in the national project: Researches based on Knowledge Management Approach Concerning Industry-University Collaboration in the Open Innovation Context (UNIinOI). This work was undertaken through the Partnerships in Priority Domains Programme-PN II, developed with the support of MEN-UEFISCDI, Project No. 337/2014 in Romania. Any findings, results, or conclusions expressed in this article belong to authors and do not necessarily reflect the views of the national authority UEFISCDI.

Author Contributions: The proposed study is part of research carried out by all the authors, within a synergic collaboration, with continuous reciprocal feedbacks during the literature studies, the writing of the text and the measurements made. All authors contributed in all phases of the work.

Conflicts of Interest: The authors declare no conflict of interest.

\section{References}

1. Natalini, D.; Bravo, G. Encouraging Sustainable Transport Choices in American Households: Results from an Empirically Grounded Agent-Based Model. Sustainability 2014, 6, 50-69. [CrossRef]

2. Nicola, D.A.; Rosen, M.A.; Bulucea, C.A.; Brandusa, C. Some Sustainability Aspects of Energy Conversion in Urban Electric Trains. Sustainability 2010, 2, 1389-1407. [CrossRef]

3. Pojani, D.; Stead, D. Sustainable Urban Transport in the Developing World: Beyond Megacities. Sustainability 2015, 7, 7784-7805. [CrossRef]

4. Jou, R.-C.; Chen, T.-Y. Willingness to Pay of Air Passengers for Carbon-Offset. Sustainability 2015, 7, 3071-3085. [CrossRef]

5. Chiu, C.-F.; Chen, M.-H.; Chang, F.-H. Carbon Dioxide Concentrations and Temperatures within Tour Buses under Real-Time Traffic Conditions. PLoS ONE 2015, 10, e0125117. [CrossRef] [PubMed]

6. Čorňák, Š.; Horák, V.; Chládek, Z.; Ulman, J. The evaluation of air quality in military vehicles. Sci. Mil. 2012, 7, 50-54.

7. Čorňák, Š.; Braun, P. The evaluation of interior car's air quality and safety of traffic. Sci. Mil. 2010, 1, 36-39.

8. Bierwirth, P.N. Carbon Dioxide Toxicity and Climate Change: A Serious Unapprehended Risk for Human Health. Available online: http://grapevine.com.au/ pbierwirth/co2toxicity.pdf (accessed on 2 July 2016).

9. Allen, J.G.; MacNaughton, P.; Satish, U.; Santanam, S.; Vallarino, J.; Spengler, J.G. Associatios of Cognitive Function Scores with Carbon Dioxide, Ventilation, and Volatite Organic Compound 12 Exposures in Office Workers: A Controlled Exposure Study of Green and Conventional Office Environments. Environ. Health Perspect. 2015. [CrossRef] [PubMed]

10. Williams, W.J. Physiological response to alterations in $\left[\mathrm{O}_{2}\right]$ and $\left[\mathrm{CO}_{2}\right]$ : relevance to respiratory protective devices. J. Int. Soc. Respir. Protect. 2010, 27, 27-51. 
11. Kajtar, L.; Herczeg, L.; Lang, E.; Hrustinszky, T.; Banhidi, L. Influence of carbon-dioxide pollutant on human well-being and work intensity. In Proceedings of the Healthy Buildings (HB 2006), Lisboa, Portugal, 4-8 June 2006; Volume I, pp. 85-90.

12. Kajtar, L.; Herczeg, L.; Lang, E. Examination of influence of $\mathrm{CO}_{2}$ concentration by scientific methods in the laboratory. In Proceedings of the 7th International Conference (Healthy Buildings 2003), National University of Singapore, Singapore, 7-11 December 2003; Volume 3, pp. 176-181.

13. Stankovic, A.; Alexander, D.; Oman, C.M.; Schneiderman, J. A Review of Cognitive and Behavioral Effects of Increased Carbon Dioxide Exposure in Humans. NASA Technical Paper. 2016. Available online: http:/ /ntrs.nasa.gov/archive/nasa/casi.ntrs.nasa.gov/20160003872.pdf (accessed on 24 June 2016).

14. Wargocki, P.; Wyon, D.P.; Sundell, J.; Clausen, G.; Fanger, P.O. The effects of outdoor air supply rate in an office on perceived air quality, Sick Building Syndrome (SBS) symptoms and productivity. Indoor Air 2000, 10, 222-236. [CrossRef] [PubMed]

15. Apte, M.G.; Fisk, W.J.; Daisey, J.M. Associations between indoor $\left(\mathrm{CO}_{2}\right)$ concentrations and sick building syndrome symptoms in US Office Buildings: an analysis of the 1994-1996 BASE Study Data (LBNL 44385). Indoor Air 2000, 10, 246-257. [CrossRef] [PubMed]

16. Chao, H.J.; Schwartz, J.; Milton, D.K.; Burge, H.A. The work environment and workers' health in four large office building. Environ. Health Perspect. 2003, 111, 1242-1248. [CrossRef] [PubMed]

17. Tietjen, G.E.; Khubchandani, J.; Ghosh, S.; Bhattacharjee, S.; Kleinfelder, J. Headache symptoms and indoor environmental parameters: Results from the EPA BASE study. Ann. Indian Acad. Neurol. 2012, 15 (Suppl. S1), S95-S99. [PubMed]

18. Mi, Y.-H.; Norbäck, D.; Tao, J.; Mi, Y.-L.; Ferm, M. Current asthma and respiratory symptoms among pupils in Shanghai, China: Influence of building ventilation, nitrogen dioxide, ozone, and formaldehyde in classrooms. Indoor Air 2006, 16, 454-464. [CrossRef] [PubMed]

19. Simoni, M.; Annesi-Maesano, I.; Sigsgaard, T.; Norbäck, D.; Wieslander, G.; Nystad, W.; Canciani, M.; Sestini, P.; Viegi, G. School air quality related to dry cough, rhinitis and nasal patency in children. Eur. Respir. J. 2010, 35, 742-749. [CrossRef] [PubMed]

20. Kim, J.L.; Elfman, L.; Wieslander, G.; Ferm, M.; Torén, K.; Norbäck, D. Respiratory health among Korean pupils in relation to home; school and outdoor environment. J. Korean Med. Sci. 2010, 26, 166-173. [CrossRef] [PubMed]

21. ANSES. Concentrations de $\mathrm{CO}_{2}$ dans L'air Intérieur et Effets sur la Santé-De I'agence Nationale de Sécurité Sanitaire de L'alimentation, de L'environnement et du Travail, Maisons-Alfort. 2013. Available online: https://www.anses.fr/en/system/files/AIR2012sa0093Ra.pdf (accessed on 24 April 2016).

22. GESTIS. Base de Données sur les Substances Dangereuses pour L'assurance Sociale Allemande des Accidents. France, 2013. Available online: http://www.dguv.de/ifa/en/gestis/stoffdb/index.jsp\# (accessed on 4 May 2016).

23. ASHRAE. Ashrae Habdbook: Heating, Ventilating, and Air-Conditioning Applications. 1999. Available online: http:/ / www.hvac.amickracing.com/Miscellaneous/HVAC_Applications_Handbook-ASHRAE.pdf (accessed on 24 June 2016).

24. OSHA. Technical Manual, TED 1-0.15A, Section VI, Chapter 2, 1999. Available online: www.osha.gov/dts / osta/otm/otm_vi/otm_vi_2.html\#2 (accessed on 24 June 2016).

25. HKEPD (Environmental Protection Department). Practice Note for Managing Air Quality in Air-Conditioned Public Transport Facilities 2015. Available online: http:/ /www.epd.gov.hk/epd/sites/default/files/epd/ english/resources_pub/publications/files/pn15_1.pdf (accessed on 24 June 2016).

26. HKEPD (Environmental Protection Department). Practice Note for Managing Air Quality in Air-Conditioned Public Transport Facilities 2003. Available online: http:/ /www.epd.gov.hk/epd/sites/default/files/epd/ english/resources_pub/publications/files/pn03_1.pdf (accessed on 24 June 2016).

27. Cooper, E.S.; West, J.W.; Jaffe, M.E.; Goldberg, H.I.; Kawamura, J.; McHenry, L.C., Jr. The relation between cardiac function and cerebral blood flow in stroke patients. 1. Effect of $\mathrm{CO}_{2}$ inhalation. Stroke 1970, 1, 330-347. [CrossRef] [PubMed]

28. Beck, J.G.; Ohtake, P.J.; Shipherd, J.C. Exaggerated anxiety is not unique to $\mathrm{CO}_{2}$ in panic disorder: A comparison of hypercapnic and hypoxic challenges. J. Abnorm. Psychol. 1999, 108, 473-482. [CrossRef] [PubMed]

29. Erdmann, C.A.; Apte, M.G. Mucous membrane and lower respiratory building related symptoms in relation to indoor carbon dioxide concentrations in the 100-building BASE dataset. Indoor Air 2004, 14 (Suppl. S8), 127-134. [CrossRef] [PubMed] 
30. Tsai, D.H.; Lin, J.S.; Chan, C.C. Office workers' sick building syndrome and indoor carbon dioxide concentrations. J. Occup. Environ. Hyg. 2012, 9, 345-351. [CrossRef] [PubMed]

31. Guais, A.; Brand, G.; Jacquot, L.; Karrer, M.; Dukan, S.; Grevillot, G.; Jo Molina, T.; Bonte, J.; Regnier, M.; Schwartz, L. Toxicity of carbon dioxide: A review. Chem. Res. Toxicol. 2011, 24, 2061-2070. [CrossRef] [PubMed]

32. Institut National de Recherche et de Sécurité, Paris (INRS). Dioxyde de Carbone, Fiche Toxicologique FT 238. 2005. Available online: http://www.inrs.fr/accueil/produits/bdd/doc/fichetox.html?refINRS=FT\%20238 (accessed on 24 May 2015).

33. Deutsche Forschungsgemeinschaft [DFG]. Arsen und anorganische Arsenverbindungen. In Gesundheitsschadliche Arbeitsstoffe: Toxicologisch-Arbeitsmedizinische Begrun-Dungen von MAK-Werten, 35, Lieferung; Greim, H., Ed.; Wiley-VCH: Weinheim, Germany, 1999; pp. 1-50. (In German)

34. Marquardt, H.; Schäfer, S.G. Lehrbuch der Toxikologie; BI-Wissenschaftsverlag, Mannheim, 1994. Available online: http://onlinelibrary.wiley.com/doi/10.1002/pauz.19970260416/abstract (accessed on 21 January 2016).

35. Abolhassani, M.; Guais, A.; Chaumet-Riffaud, P.; Sasco, A.; Schwartz, L. Carbon dioxide inhalation causes pulmonary inflammation. Am. J. Physiol. Lung. Cell. Mol. Physiol. 2009, 296, L657-L665. [CrossRef] [PubMed]

36. Olsen, B.W. Indoor Environment-Health, Comfort and Productivity. In Proceedings of the 8th REHVA World Congress (Clima 2005), Lausanne, Switzerland, 9-12 October 2005. Available online: http:/ / citeseerx. ist.psu.edu/viewdoc/download?doi=10.1.1.524.6423\&rep=rep1\&type=pdf (accessed on 2 April 2016).

37. Coley, D.A.; Beisteiner, A. Carbon dioxide levels and ventilation rates in schools. Int. J. Vent. 2002, 1, 45-52. [CrossRef]

38. Satish, U.; Mendell, M.J.; Shekhar, K.; Hotchi, T.; Sullivan, D.; Streufert, S.; Fisk, W.B. Is $\mathrm{CO}_{2}$ an Indoor Pollutant? Direct Effects of Low-to-Moderate $\mathrm{CO}_{2}$ Concentrations on Human Decision-Making Performance. Environ. Health Perspect. 2012, 120, 1671-1677. [CrossRef] [PubMed]

39. Twardella, D.; Matzen, W.; Lahrz, T.; Burghardt, R.; Spegel, H.; Hendrowarsito, L.; Frenzel, A.C.; Fromme, H. Effect of classroom air quality on students' concentration: Results of a cluster-randomized cross-over experimental study. Indoor Air 2012, 22, 378-387. [CrossRef] [PubMed]

40. Norbäck, D.; Nordström, K. An experimental study on effects of increased ventilation flow on students' perception of indoor environment in computer classrooms. Indoor Air 2008, 18, 293-300. [CrossRef] [PubMed]

41. Norbäck, D.; Wieslander, G.; Zhang, X.; Zhao, Z. Respiratory symptoms, perceived air quality and physiological signs in elementary school pupils in relation to displacement and mixing ventilation system: An intervention study. Indoor Air 2011, 21, 427-437. [CrossRef] [PubMed]

42. Norbäck, D.; Nordström, K.; Zhao, Z. Carbon dioxide $\left(\mathrm{CO}_{2}\right)$ demand-controlled ventilation in university computer classrooms and possible effects on headache, fatigue and perceived indoor environment: An intervention study. Int. Arch. Occup. Environ. Health 2013, 86, 199-209. [CrossRef] [PubMed]

43. Smedge, G.; Mattsson, M.; Walinder, R. Comparing mixing and displacement ventilation in classrooms: Pupils' perception and health. Indoor Air 2011, 21, 454-461.

44. Grady, M.; Jung, H.; Kim, Y.; Park, J. Vehicle Cabin Air Quality with Fractional Air Recirculation, SAE Technical Paper. 2013. Available online: http://www.engr.ucr.edu/ heejung/publications/2013CO2-exp.pdf (accessed on 29 June 2016).

45. EIGA (European Industrial Gases Association). Carbon Dioxide Physiological Hazards-Not Just an Asphyxiant. Available online: https://www.eiga.eu/index.php?id=294\&tx_abdownloads (accessed on 30 June 2016).

46. Fisk, W.J.; Satish, U.; Mendell, M.J.; Hotchi, T.; Sullivan, D. Is $\mathrm{CO}_{2}$ an Indoor Pollutant? Higher Levels of $\mathrm{CO}_{2}$ May Diminish Decision Making Performance. ASHRAE J. 2013, 55, 84-85.

47. Groeger, J.A. Understanding Driving: Applying Cognitive Psychology to a Complex Everyday Task; Psychology Press: Philadelphia, PA, USA, 2000.

48. Michon, J.A. A critical view of driver behaviour models: What do we know, what should we do? In Human Behaviour and Traffic Safety; Evans, L., Schwing, R.C., Eds.; Plenum Press: New York, NY, USA, 1985; pp. 485-520.

(C) 2016 by the authors; licensee MDPI, Basel, Switzerland. This article is an open access article distributed under the terms and conditions of the Creative Commons Attribution (CC-BY) license (http:/ / creativecommons.org/licenses/by/4.0/). 